\title{
КОНЦЕПТУАЛЬНА СХЕМА ПОБУДОВИ МОДЕЛІ ЗАГАЛЬНООБОВ'ЯЗКОВОГО ДЕРЖАВНОГО СОЦІАЛЬНОГО МЕДИЧНОГО СТРАХУВАННЯ В УКРАЇНІ
}

\author{
Є. В. Горшков
}

\author{
Національна медична академія післядипломної освіти імені П.Л. Шупика
}

\begin{abstract}
У статті розглянута концептуальна схема побудови моделі загальнообов'язкового державного соціального медичного страхування. Запропонована модель розрахунку страхового внеску з використанням ризикової надбавки та дисперсії.
\end{abstract}

Ключові слова: соціальне страхування, модель

\section{КОНЦЕПТУАЛЬНА СХЕМА ПОСТРОЕНИЯ МОДЕЛИ ОБЩЕОБЯЗАТЕЛЬНОГО ГОСУДАРСТВЕНОГО СОЦИАЛЬНОГО МЕДИЦИНСКОГО СТРАХОВАНИЯ В УКРАИНЕ}

\author{
Е. В. Горшков \\ Национальная медицинская академия последипломного образования имени П.Л. Шупика \\ В статье рассмотрена концептуальная схема построения модели общеобязательного государственного социаль- \\ ного медицинского страхования. Предложенная модель расчета страхового взноса с использованием рисковой \\ надбавки и дисперсии.
}

Ключевые слова: социальное страхование, модель

\section{CONCEPTUAL SCHEME OF MODEL STRUCTURE OF COMPULSORY FOR ALL STATE SOCIAL MEDICAL INSURANCE IN UKRAINE}

\author{
Ye. V. Horshkov \\ National Medical Academy of Post-Graduate Education by P. L. Shupyk
}

\begin{abstract}
In this article there has been presented the conceptual scheme of the model structure of compulsory for all state social medical insurance. There has been proposed the calculation model of insurance payment using risk extra charge and dispersion.
\end{abstract}

Key words: social insurance, model.

Вступ. Накопичений багаторічний світовий досвід у галузі медичного страхування свідчить про високу ефективність різних моделей і систем медичного страхування та страхування здоров'я. До теперішнього часу визначаються три основні види фінансування охорони здоров'я: державне, через обов'язкове та добровільне медичне страхування та змішана форма.

Слід зауважити, що ці види у відокремленому вигляді практично не використовуються ні в одній державі, проте в деяких державах вони займають домінуюче положення. Так, наприклад, в Англії, Ірландії,
Шотландії, Італії та Данії домінує державна система фінансування. В таких країнах як Німеччина, Франція, Австрія, Бельгія, Нідерланди, Швеція та Японія домінує система обов'язкового медичного страхування, в той час як у США має перевагу змішана форма фінансування медичної допомоги, близько $90 \%$ американців користуються послугами приватних страхових компаній [1].

\section{Основна частина.}

Враховуючи історичні, ментальні, економічні особливості нашої країни, вважаємо доцільним побудову системи моделі загальнообов'язкового державного 
соціального медичного страхування (ЗОДСМС) на основі моделі О. Бісмарка, яка модифікована із застосуванням засад моделі В. Бевериджа в частині фінансування пріоритетних державних програм, наукових досліджень тощо.

Модель Бісмарка, або соціально-орієнтована, основним чином грунтується на обов'язковому соціальному страхуванні всіх жителів аж до певного рівня доходу. Така система фінансується через цільові внески працедавців та працівників, а також бюджетних субсидій із загальних або цільових надходжень. До групи з такою моделлю належать Австрія, Бельгія, Франція, Німеччина, Нідерланди, Люксембург, а також Швейцарія [2].

Вивчення усього комплексу проблем, пов'язаних 3 організацією фінансового забезпечення охорони здоров'я на страхових засадах, дало підставу стверджувати, що в Україні доцільним є запровадження централізованої бюджетно-страхової моделі охорони здоров'я. Зміст їі полягає в диверсифікації надходження коштів за рахунок двох джерел - коштів бюджетної системи та страхових внесків. Доцільним $\epsilon$ додаткове залучення коштів через механізм добровільного медичного страхування та приватний сектор медицини.

Зупинимося детальніше саме на коштах загальнообов'язкового державного соціального медичного страхування, оскільки навколо впровадження цього джерела фінансування виникає найбільше суперечок 3 приводу того, як має бути побудована система такого страхування, хто має бути платником, який обсяг послуг має бути гарантований тощо.

Чіткого визначення потребує питання кількості суб'єктів загальнообов'язкового державного соціального медичного страхування.

Сама назва цього виду страхування говорить про те, що воно повинно мати обов'язковий характер i покривати витрати на лікування через офіційно встановленого платника, який повинен бути неурядовою організацією.

У більшості країн Західної Європи обов'язкове медичне страхування побудоване на системі єдиного платника. Ним може бути бюджет, єдиний страховий фонд або ж неприбуткові страховики з жорстким регуляторним механізмом їхньої діяльності.

Причин, чому участь комерційних страховиків в загальнообов'язковому державному соціальному медичному страхуванні не є бажаною, декілька:

1. Маючи на меті отримання прибутку, страховики прагнутимуть зменшення потенційних витрат, а тому шукатимуть способи залучати до страхування більш здорових людей і відмовляти у страхуванні людям зі слабшим здоров'ям. А з боку держави простежити за такими випадками складно.

2. Ще одним аргументом проти участі комерційних страховиків у загальнообов'язковому державному соціальному медичному страхуванні вважаємо значний ризик банкрутства, особливо невеликих ком паній. Пояснюється це тим, соціальне медичне страхування передбачає рівні умови для всіх громадян, а тому розмір страхових платежів не залежить від індивідуальних ризиків, що не дозволяє страховикові, як це відбувається при добровільному медичному страхуванні, компенсувати підвищений ризик зростанням страхового тарифу, що за умови нерівномірного розподілу ризиків може призвести до значних збитків.

3. За умови участі значної кількості страховиків відбуватиметься розпорошеність страхових коштів і складність контролю за їх рухом, а це робить систему ОМС ненадійною. Нерегульована система конкуруючих страховиків у разі запровадження обов'язкового медичного страхування аж ніяк не сприяє реалізації принципів соціальної справедливості.

4. Конкуренція, необхідністю якої страховики аргументують свою участь, повинна перш за все існувати серед медичних закладів, адже саме вони втілюють Конституційні права громадян на охорону здоров'я і від них залежить якість медичних послуг.

Щодо можливості існування декількох фондів, вважаємо цей варіант не оптимальним, оскільки він пов 'язаний зі значними труднощами концентрації ризиків і відповідного розподілу фінансових ресурсів. Це пов'язано з тим, що різні регіони країни, а також різні групи населення характеризуються значним розривом в соціально-економічних умовах, різним рівнем захворюваності. За таких умов вірогідна така ситуація, коли в одному фонді акумулюються значно вищі ризики, ніж в інших, а відносний обсяг фінансових ресурсів при цьому буде меншим. Тому принципи соціальної справедливості вимагають, щоб фонди, які об'єднують людей з низькими витратами на лікування і високими доходами, субсидували фонди, в яких концентруються застраховані з білыш високим рівнем витрат на лікування і низьким рівнем доходів. Організація такого перерозподілу фінансових ресурсів вимагає створення складного і точного механізму вирівнювання фінансових умов, в яких опиняються фонди медичного страхування.

Очевидним виходом $\epsilon$ функціонування у сфері ОМС єдиного страхового фонду - Фонду медичного страхування. 


\section{Завдання Фонду медичного страхування.}

Фонд медичного страхування повинен бути самостійною недержавною некомерційною організацією, що є юридичною особою і працює відповідно до чинного законодавства. Він повинен бути сформований на державному і регіональному рівнях.

Фонд медичного страхування повинен займатися:

- акумуляцією коштів на ОМС;

- здійсненням виплат медичним закладам за лікування застрахованих;

- розробкою та впровадженням правил страхування;

- формуванням баз даних платників страхових внесків, здійсненням контролю за своєчасною і повною сплатою страхових внесків;

- здійсненням контролю за якістю медичної допомоги, що надається медичними установами;

- розробленням пропозицій щодо встановлення та регулювання страхових тарифів для страхувальників;

- участю у фінансуванні державних і регіональних програм у сфері охорони здоров'я;

- створенням резервних фондів, що забезпечують стабільність функціонування системи ОМС.

Страхувальник, згідно з договором, укладеним ним з Фондом медичного страхування, щомісяця сплачує страховий внесок встановленого розміру, а Фонд медичного страхування, зі свого боку, бере на себе зобов 'язання організувати надання медичної допомоги застрахованим, а також фінансувати здійснення профілактичних заходів з метою запобігання захворювань.

Окрім Фонду медичного страхування суб'єктами загальнообов'язкового державного соціального медичного страхування є страхувальники, лікувальнопрофілактичні установи та самі застраховані.

Страхувальниками працюючого населення повинні на час перехідного етапу стати роботодавці. Але 3 часом, по закінченні перехідного етапу, обов'язок зі сплати внеску на ЗОДСМС варто розподілити між роботодавцем та самим працівником.

Чіткого визначення потребує питання встановлення страхувальника для непрацюючого населення, дітей, пенсіонерів, інвалідів тощо. Тут доцільно застосувати схему багатоканального наповнення фонду медичного страхування. Наприклад, за пенсіонерів повинен сплачувати страховий внесок Пенсійний фонд, за безробітного - Фонд по безробіттю, за інвалідів - Фонд від нещасного випадку на виробництві, за дітей, студентів, - орган місцевого самоврядування, за державних службовців - державний бюджет.

Обсяг медичної допомоги, що надається застрахованим, повинен бути конкретизований у загально- державній, регіональних та інших програмах в сфері загальнообов'язкового державного соціального медичного страхування. Ті медичні послуги, що не ввійшли до програм загальнообов'язкового державного соціального медичного страхування з огляду на надто високу їх вартість, але є необхідними для відновлення здоров'я, наприклад онкологічна допомога, допомога ВІЛ-інфікованим, діабетикам, хворим на туберкульоз тощо, повинні визначатися загальнодержавними цільовими програмами і фінансуватися за рахунок бюджетних коштів.

\section{Основні положення базової програми.}

Базова програма загальнообов'язкового державного соціального медичного страхування (Базова програма) повинна затверджуватись Кабінетом Міністрів України за поданням центральних органів виконавчої влади в сфері охорони здоров'я та фінансів, Фонду медичного страхування України. На основі Базової програми мають бути розроблені регіональні та інші програми в сфері загальнообов'язкового державного соціального медичного страхування, що можуть розширювати Базову програму 3 врахуванням специфічних ризиків, притаманних даному регіону. Обсяг та умови надання медичної допомоги, передбачені регіональними програмами, не можуть бути нижчі за встановлені Базовою програмою.

\section{Розмір страхового внеску.}

Важливим питанням є встановлення адекватного розміру страхового внеску. Він повинен встановлюватися у відсотках до заробітної плати, щоб усі страхувальники були у рівних умовах, тобто внески не повинні мати регресивний характер.

На початковому етапі запровадження обов'язкового медичного страхування доцільно передбачити так званий перехідний період, протягом якого сплата страхових внесків повинна здійснюватися виключно роботодавцями.

Можливо, це не зовсім справедливо по відношенню до останніх, але такий захід повинен носити тимчасовий характер і має на меті усунути суперечності між конституційним правом громадянина на безоплатність медичної допомоги та медичним страхуванням, що передбачає сплату страхових внесків. В перспективі, якщо система загальнообов'язкового медичного страхування доведе свою економічну та соціальну ефективність, неминучим є частковий перегляд статті 49 Конституції України в напрямку задіяння громадян у частковому фінансуванні сфери охорони здоров'я, приймаючи до уваги те, що безоплатність медичної допомоги забезпечується в межах фінансових можливостей держави, яких недо- 
статньо для здійснення повного обсягу медичних послуг належної якості.

Аби уникнути навмисного заниження роботодавцями офіційної заробітної плати найманих працівників, що має на меті зменшення розміру страхових внесків, необхідно законодавчо забезпечити можливість віднесення коштів, направлених на сплату страхових внесків з загальнообов'язкового державного медичного страхування, на валові витрати підприємства.

Встановлення розміру страхового внеску потребує особливо виваженого підходу з огляду на те, що він, 3 одного боку, повинен забезпечити належне за обсягом наповнення бюджету фонду обов'язкового медичного страхування, а з іншого боку, не повинен чинити фінансового тиску на страхувальників.

Для розрахунку приблизного розміру внеску на обов'язкове медичне страхування за основу доцільно взяти модель розрахунку внеску, запропоновану О. С. Губар, але $з$ внесенням деяких коректив.

Суть запропонованої моделі полягає у розрахунку розміру страхового тарифу на основі показника середньорічного дефіциту витрат лікування на одну середньостатистичну особу з використанням ризикової надбавки (1) та дисперсії.

Внесення коректив доцільне саме у розрахунок суми дефіциту коштів на одну середньостатистичну особу.

В основу моделі розрахунку взято принцип варіації (variance principle):

$C=M X+\lambda D X, \lambda>0$,

де: $C$ - величина страхового внеску;

$X$ - випадкова величина можливого сумарного збитку;

$M X$ - середньорічна сума дефіциту видатків на лікування однієї середньостатистичної особи;

$\mathrm{DX}$ - дисперсія.

Середньорічна сума дефіциту видатків на лікування однієї середньостатистичної особи та дисперсія розраховані за такими формулами:

$$
\begin{aligned}
& M X=\frac{1}{n} \sum_{i=1}^{n} x_{i}, \\
& D X=\frac{1}{n} \sum_{i=1}^{n} x_{i}^{2}-(M X)^{2} .
\end{aligned}
$$

де $n$ - кількість досліджуваних періодів (років), $n=5$;

$x_{\underline{i}}-$ середньорічний дефіцит витрат на лікування $i$ го періоду.

Розрахунок величини витрат на медичне обслуговування однієї середньостатистичної особи необхід- но здійснювати відповідно до нормального розподілу ймовірностей (розподіл Гаусса). Як відомо, це розподіл імовірностей випадкової величини, що характеризується щільністю ймовірності:

$f(x ; \mu, \sigma)=\frac{1}{\sigma \sqrt{2 \pi}} \exp \left(-\frac{(x-\mu)^{2}}{2 \sigma^{2}}\right)$,

де $\sigma$ - середнє квадратичне відхилення, що дорівнює $\sqrt{D}$;

$\mu$ - середньорічна сума дефіциту видатків на лікування однієї середньостатистичної особи;

$x$ - дефіцит коштів на одну середньостатистичну особу за рік.

Актуальною проблемою у разі вибору схеми організації ЗОДСМС з єдиним платником, а в запропонованій нами концептуальній схемі платником є Фонд медичного страхування, є недопущення зловживань монопольним становищем та використання грошей страхового фонду не за цільовим призначенням.

Для цього за його діяльністю повинен бути постійний контроль, але контроль не лише з боку держави, а її з боку всіх зацікавлених осіб. Такий контроль можна певною мірою забезпечити створенням спеціального наглядового органу, до складу якого повинна входити рівна кількість представників від кожної зацікавленої сторони: держава, представники медичних установ, представники профспілок. Але лише такий захід не забезпечить всеосяжного контролю.

Вся інформація щодо діяльності Фонду, руху коштів, акумульованих у Фонді, фінансування Фондом спеціалізованих програм у сфері охорони здо-

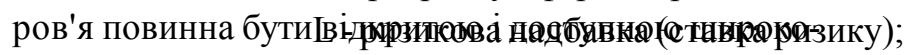
му загалу, тобто необхідно забезпечити ії оприлюднення по закінченні кожного звітного року в офіційних державних виданнях.

Держава в особі Міністерства охорони здоров'я повинна розробити державну програму ЗОДСМС, а місцеві органи влади відповідно до умов кожного регіону конкретизують і доповнюють базову державну програму. Територіальні програми повинні враховувати локальні чинники ризику і передбачати не лише медичні послуги, спрямовані на лікування громадян, а й профілактичні заходи, метою яких має бути запобігання негативному впливу характерних для цього регіону факторів ризику. Так, наприклад, на Закарпатті, зважаючи на характерний для цієї області йододефіцит, в територіальні програми доцільно було б включити профілактичні медогляди, спрямованні на ранню діагностику захворювань щитоподібної залози, медикаментозну профілактику тощо. 
Але незмінним є те, що застрахований має право отримати необхідну йому для підтримання життєдіяльності і відновлення здоров'я медичну допомогу у повному обсязі і належної якості. В разі недостатності на таку допомогу коштів Фонду, лікування оплачується за рахунок державних коштів.

Можлива така ситуація, що клієнт окрім полісу ЗОДСМС має поліс добровільного медичного страхування. В такому випадку вважаємо справедливим такий розподіл відшкодування вартості медичних послуг: вартість послуг, які передбачені полісом ДМС, відшкодовується страховою компанією, але в межах страхової суми, вартість наданих послуг в розмірі перевищення страхової суми за полісом ДМС повинна бути відшкодована Фондом медичного страхування.

Але більш доцільним виходом з такої ситуації вважаємо розробку спеціальних сумісних програм ДМС та ЗДСМС, які мають забезпечити повний спектр медичної допомоги та виключити можливість подвійної оплати за одну й ту саму медичну послугу.

Окрім цього, доцільно було б скористатися досвідом Німеччини в галузі медичного страхування i передбачити можливість виходу із системи ЗОДСМС для тих громадян, чий дохід перевищує певний встановлений рівень [3]. Але необхідною умовою для цього має бути участь такого громадянина у системі добровільного медичного страхування. Тобто, звільнення громадянина, чий дохід перевищує рівень, встановлений для обов'язкової участі в ЗОДСМС, повинно відбуватись в такій послідовності:

\section{Лтература.}

1. Філатов В. М. Інституційні зміни у сфері охорони здоров'я в умовах транзитивної економіки. В. М. Філатов // Наукові праці ДонНГУ Серія: економічна. Випуск 103-4. - 2006. - С. 92 - 96.
- на початку року громадянин заключає договір добровільного медичного страхування 3 вибраною ним страховою компанією;

- у Фонді медичного страхування громадянин заповнює заяву про відмову від ЗОДСМС і разом з копією полісу ДМС та довідкою про доходи подає іiі відповідний відділ фонду;

- після аналізу поданих документів Фонд приймає рішення про звільнення громадянина від сплати внесків на ЗОДСМС терміном на 1 рік.

В наступному році процедуру необхідно проходити знову.

Висновки. На найближчу перспективу до пріоритетних напрямків впровадження і розвитку ЗОДСМС в Україні доцільно віднести:

- прийняття проекту Закону "Про загальнообов'язкове державне соціальне медичне страхування";

- розроблення єдиних стандартів лікувально-діагностичного процесу;

- узгодження величини нового страхового внеску iз чинним механізмом оподаткування;

- розроблення бюджету фонду ЗДСМС, особливо в частині прогнозування необхідного обсягу фінансових ресурсів з урахуванням реальних потреб адміністративно-територіальних одиниць;

- виділення пріоритетних напрямів використання коштів;

- забезпечення контролю за витрачанням коштів ЗДСМС за призначенням через створення спеціального наглядового органу;

- вибір оптимального методу оплати медичної допомоги.

2. Губар О. Медичне страхування у країнах Європейського союзу / О. Губар // Фінанси України. -2003. - №> 7. - С. 130- 136. 3. Ресурc: www.bmg.bund.de // Міністерство охорони здоров'я Німеччини 